\title{
Inquisición, erotismo, pornografía y normas literarias en el siglo XVIII
}

IRIS M. ZAVALA

Universidad de Utrecht

En pulcra entrada del diccionario, pornografía es «la cualidad de los escritos que excitan morbosamente la sexualidad». Según Corominas no se registra en español hasta 1925; sus raíces son el gr. pornographus: porne, prostituta y grapho, describir. Esta escueta definición aparece en los diccionarios, conjunto léxico institucionalizado que registra el lenguaje como manifestación o forma de expresión social de los grupos en el poder. Volviendo al diccionario, clandestino se define como «hecho que se oculta a las autoridades», sea reunión, sea publicación. De un mismo tenor: encubierto, a hurtadillas, subrepticio, a escondidas, furtivamente, en la oscuridad, en la sombra; oculto, ilegal, prohibido. Estas definiciones abarcan buena parte de la literatura innovadora del setecientos. A través de estos registros de connotaciones y denotaciones, y sus derivados de «erotismo", «lascivo», «obsceno», la censura inquisitorial imponía sus normas morales y estéticas.

La Iglesia y el Estado son receptores/lectores responsables del acto y circuito de comunicación; ambos son agentes privilegiados, que preci- 
san el discurso autoritario normativo de la teología, dominante en la época. Asimismo, ambas instituciones ejercen una función restrictiva: centralizan los fenómenos verbales a través de un lenguaje autoritario y monológico, guiados por el interés de imponer un discurso único y unas normas literarias más o menos únicas. Interceptan el diálogo creador entre autor y receptor; con esto se produce otro hecho que afecta la relación emisor-receptor: se cambian y se apropian los mensajes. El autor pierde la iniciativa del contacto, que corresponde estrictamente a este receptor interesado. El análisis de sus códigos literarios nos permite reconstruir, sobre la base de testimonios dispersos, el sistema de comunicación literaria, el proceso de producción y de recepción en dicho contexto. El acto comunicativo carece así de un contexto compartido por el destinatario y el emisor. Los calificadores de la Inquisición y del Estado son mediadores entre autor y público; el lector coetáneo concreto pierde la posibilidad de acceso real. En cambio, el censor descifra el texto, limitándolo a un código determinado, llegando incluso a modificar lo que M. Baktin llama memoria genérica ("genre memory»): un campo intersubjetivo que supone elección frente a la tradición y normas literarias previas, fundamental en la evolución literaria ${ }^{1}$.

Desde esta delicada perspectiva de comunicación, la censura desempeñó un papel activo y obstaculizó y fijó sus propias normas literarias, a partir de su moral rigorista, limitando un repertorio de posibilidades. Nos centraremos en su hostilidad particular hacia un género específico: la novela. La narrativa se transforma a finales del siglo de las luces en una especie de arte de periferia, situada realmente en la frontera legalizada de la tradición literaria coetánea. Admitido este marco de horizonte histórico en el setecientos, podremos precisar el efecto del vacío de ciertas formas novelísticas, la falta de adaptaciones y de variaciones en los niveles de formación de tradiciones y normas literarias. El emisor se vio obligado a elegir su mensaje entre un reducido repertorio de los tipos o géneros que la norma legalizada ofrece. Esta ruptura persistirá hasta mediados del siglo XIX; y aquí, en la manera en que la censura limita el mensaje, encontramos —creo- un elemento decisivo en la historia literaria.

La labor censora de la Inquisición ha sido minuciosamente expuesta a través de datos excepcionales. En estas páginas propongo algunos

1 Parto de un esquema de la teoría de la recepción formulada por Jauss (1978), y de algunos conceptos de la recepción textual de Iser (1975). Desde esta perspectiva, creo, se puede situar la censura como mediadora en la tradición literaria. El terreno queda abierto. El concepto de memoria genérica, que tomo de Baktin (1981), es central en la evolución literaria. 
aspectos complementarios, no menos decisivos: el papel que ésta ha desempeñado en la tradición literaria. En cuanto receptor, el Santo Oficio representa un lector doblemente privilegiado: es intérprete y crítico literario. Esta última función ha pasado inadvertida en estudios teóricos de recepción literaria; el calificador es un receptor cuyo acto de lectura le permite rechazar, aceptar o alterar los textos para adaptarlos a su acto de lectura y a su función de intérprete. Las listas de libros prohibidos que conocemos, las expurgaciones, alteraciones o prohibiciones revelan, desde esta óptica, una aguda inflexión en la tradición literaria, puesto que el lector inquisitorial tiene el poder de alterar, interceptar o desviar las innovaciones. Interviene como fuerza paralizadora del diálogo o polémica intertextual, necesarios para el desarrollo literario. Sus efectos serán inmediatos sobre la producción novelística: reduce el discurso de la polisemia a la monosemia.

Me centraré en algunos casos específicos - la recepción del enciclopedismo y de las «historias fingidas» o novelas, en la España del siglo XVIII ${ }^{2}-$. Los datos son conocidos: si bien existían la censura y la Inquisición desde el siglo XVI, su función en general se había reducido al discurso teológico y a los libros en materia de fe y religión. Dentro de estas exigencias, se expurgó una alusión paulina de El Quijote; el Lazarillo se prohibió totalmente por sus referencias religiosas, pero luego fue autorizado en la edición expurgada de 1573; se expurgaron obras de Quevedo, y en 1627 se mandaba recoger las Obras en verso del Homero español, Góngora, acusado de lascivo, picaril, verde y picante, además de que el texto estaba lleno de palabras sucias y deshonestas (D. Alonso, 1963). A partir de 1752, con Fernando VI, la censura se recrudeció debido a la gran cantidad de libros y papeles clandestinos que circulaban en los Reinos. Se impuso la censura previa (también en el siglo XIX y en la España franquista), y son frecuentes las visitas a librerías para el control de la importación de libros, y las sentencias y las denuncias contra editores e impresores. Se persiguen, en particular, las publicaciones clandestinas; es decir, ocultas, ilegales, prohibidas. Clandestino supone -desde estos parámetros - cuanto estuviera contra la religión y el Estado, o bien, la publicación que no pagaba tasas (Zavala, 1975 y 1978).

Tenemos un conocimiento muy imperfecto de la circulación de obras clandestinas nacionales y extranjeras. Los archivos de la Inquisición son muy fragmentarios; no obstante estas limitaciones, podemos

2 Extraigo datos sobre los documentos y las listas de libros del libro de Defourneaux (1973), además de procesos que he trabajado antes (Zavala, 1978). Me apoyo en estos documentos para analizar la función inquisitorial dentro del marco propuesto. 
afirmar que la censura gubernativa en España se recrudeció después de 1786, con el «cordón sanitario» promulgado a raíz de la Revolución francesa (Defourneaux, 1973; Herr, 1964). Pero a partir de 1750 el enemigo principal es el filósofo o enciclopedista. No sólo se persiguen entonces pasajes sospechosos, sino que se prohíben incluso libros que circulaban antes con el propósito de defender el orden social. La literatura filosófica y la novela ocupan el primer lugar en los edictos inquisitoriales en adelante.

Resumamos una historia que no por conocida se debe olvidar: la Inquisición no es un rígido monolito; los grados de tolerancia varían de acuerdo a los tribunales locales (quince, además de los tres de América y el de Corte), a la época histórica y al calificador. Si bien con Carlos II su papel estaba muy atenuado, cobró vigor con Fernando VI y con Carlos III, aunque hubo situaciones de tolerancia entre 1768 y 1790 y de vez en cuando dejaba sentir su poder con sonados autos de fe. Tal el del peruano Pablo de Olavide, condenado en 1778 en Sevilla, zona de un celoso guardián de la fe, el comisario Pedro Sánchez Bernal, responsable de un eficaz control entre 1772 y 1785 . En nueve años de excelente labor logró incautar más de 8.000 libros (Defourneaux, p. 122); otros no le irían a la zaga. Hacia esa misma época se condenó a Zerain (Zavala, 1969), y en adelante surgieron encuentros con algunos ilustrados -Iriarte, Moratín, Jovellanos, se destituyó a Campomanes-. Todo este clima represivo debe leerse a la luz de las luchas entre Iglesia y Estado.

Pero retomemos el hilo centrándonos sobre todo en los adalides de la modernidad, y sus defensas del pensamiento secularizado y laico -en particular, la literatura de ficción extranjera, francesa, sobre todo-. En primer lugar, Voltaire, que se inscribió en el Indice en 1776 por sus Contes et romans philosophiques, y algo después, sus dos cuentos más célebres, Candido, o el optimismo, y Zadig, o el destino (Defourneaux, p. 161). El calificador de los cuentos, lector culto, no sólo se atiene a la acusación de deísta; el problema es tanto más grave -según sus criterios- porque «divierte y arrastra al lector». Zadig era cuento muy conocido. En ligera variante, el documento que se conserva del edicto en México revela que los calificadores estaban inseguros respecto a la paternidad de esta obra, pero, por atribuírsela a Voltaire, se prohibió en 1790. Para complicar algo más las cosas, en 1806 se inscribió en el Indice una traducción española del cuento con fórmula equívoca, pues aparece bajo la autoría de M. de Vadé, seudónimo de Voltaire (Defourneaux, p. 163).

Sus tragedias gozaron de cierto éxito en los medios ilustrados; al- 
guna incluso se llegó a representar, sin nombre de autor. Tardíamente se prohibieron La muerte de César, en traducción del ministro de Justicia, Urquijo, y Mahoma o el falso profeta, en edicto de 1805 . No le faltó perspicacia al calificador que la examinó, al señalar que es bien notoria la impiedad de Voltaire, y cualquier obra suya debe ser recelada. Y añade que deben ser sospechosas en todo momento:

Aun cuando trata de materias de pura literatura y que no tienen concernencia con nuestra sagrada religión [...] no deja de manifestar sus impíos sentimientos y esparcir las semillas de su incredulidad (Defourneaux, p. 164).

La lista volteriana no se limita a estos títulos; figuran textos de historia, filosofía. Sus obras en 30 volúmenes se prohibieron en Madrid en 1764, y fueron figurando nominalmente obras concretas en años subsiguientes. Pero su semilla había germinado - dejó alguna huella en el teatro y en algunos ilustrados de quienes era amigo personal-. El adjetivo volteriano y el nombre abstracto volterianismo se registraban todavía en el diccionario como

la persona que se burla irreverentemente de cosas generalmente respetadas o hace crítica de cosas a las que, en general, se tiene por inatacables; particularmente de cosas de carácter religioso; así como de los escritos o dichos en que se hace esa burla o crítica.

El volterianismo es aún hoy una actitud o manera de pensar, tal cual la definió el lenguaje autoritario en el siglo XVIII. Se ha empleado como etiqueta en la cadena de nombres esgrimidos contra el pensamiento liberal laico - volterianos, rusonianos, ateos, libertinos, materialistas, deístas, masones, todos ellos provienen de estas fechas-. En cuanto receptor privilegiado, la censura expropió el significado real, y lo concretó en las denotaciones que han llegado hasta nosotros.

Jean Jacques Rousseau, si es posible, causó mayores temores que Voltaire entre los calificadores/lectores; el famoso Discours sur les origines de l'inegalité se prohibió en 1756 , al año de su aparición. Un decreto advertía que se leían otras del mismo autor; en 1764 se prohibieron simultáneamente Cartas de dos amantes y el Emilio, ambas calificadas de heréticas, inductivas al deísmo y al materialismo. Conviene recordar que ambos textos son del género novelístico. Pero el calificador/lector anticipa la circulación de otras obras de Rousseau, y desde esta fecha se declaran todas prohibidas como de autor hereje que

siembra errores opuestos a la religión, a las buenas costumbres, al gobierno civil y justa obediencia debida a los legítimos soberanos y superiores (Defourneaux, p. 150).

Sin embargo, no figura en el Indice el Contrato social (1762), aunque caen en el mismo saco las Confesiones y el melodrama Pygmalion 
(Rea Spel, 1938). Un edicto de México de 1803 contra la novelita anónima Cornelia Bororquia, o la víctima de la Inquisición, publicada en París en 1800 , le adjudica la paternidad al traductor castellano del Contrato social (Londres, 1799), que no es otro que el famoso abate Marchena, traductor también del Emilio en 1817, en edición de Burdeos. Este fugitivo español republicano, se incorporó al partido girondino y en 1792 incitaba a los españoles a unirse a la revolución desde Bayona y Perpiñán (Morel Fatio, 1897; Sarrailh, 1954; Defourneaux, p. 131; Herr, cap. VI).

Algo se difundió Rousseau y dejó alguna huella (si bien efímera) en la narrativa. En 1787 la Inquisición incautó la novela pedagógica $E l$ Eusebio, del ex-jesuita Pedro Montengón, residente en Italia. La censura provocó un embargo, pues la novela había aparecido el año anterior con licencia del Gobierno; la prohibición se pronunció en 1798, más de diez años después, si bien el autor apeló varias veces y prometió retocarla. La novela -más mencionada que leída hoy día- propone una moral racional, y sostiene que ésta nada tiene en común con la revelada. De filiación parecida es La Serafina (1798), de José Mor de Fuentes, traductor de Rousseau y de Goethe, y buen conocedor de Richardson (autor que Cándido María Trigueros alababa al filo del siglo, cf. Mis pasatiempos, I, Madrid, 1804, p. xv).

La novela racionalista de filiación rusoniana no logró crear adaptaciones ni tradición, hasta donde sabemos - la censura impidió su concreción en España-. Montengón y Mor de Fuentes siguen siendo hoy grandes desconocidos que debiéramos rescatar del silencio para la historia literaria. En cuanto nuevo estilo de novelar esta narrativa no se concretó; la función dominante de la censura impidió la formación de este género como tradición literaria (Zavala, en prensa). Excepción sea hecha de Cornelia Bororquia, excelente ejemplo de novela epistolar anticlerical, atribuida a Luis Gutiérrez, ex-fraile trinitario (Ferreras, 1973), con múltiples ediciones. Hoy día es una rareza bibliográfica y casi ejemplar único de la narrativa racionalista anticlerical.

Voltaire y Rousseau fueron, cada cual a su manera, innovadores del cuento y la novela. Candide se distingue como uno de los más notables ejemplos de cuento filosófico y político, con su utopía del Dorado; el Emilio está considerado como una de las cumbres de la novela racionalista, por su nueva ética laica. La extensa catalogación de Juan Ignacio Ferreras (1979) no registra novelas análogas en España -excepción sea hecha de las ya mencionadas-. Y el género utópico, aún desconocido, no se desarrolló extensamente, si bien se conoció alguna, pues en 1778 la Inquisición y el Consejo de Castilla condenaban $L$ 'an 
deux mille quatre cent quarante, de Sebastián Mercier, como peligrosa al Estado (Zavala, 1969). El cuento filosófico no tendrá cultivadores hasta el siglo XIX, y por lo pronto, conocemos muy pocos ejemplos de novela utópica - valga recordar La Sinapia, descubierta en fecha reciente (F. López, 1981), así como un Tratado de la monarquía columbina que acaba de publicarse (Alvarez Miranda, 1980)-. En cambio, cientos son las entradas de utopía en Francia (Backzo, 1971). La falta de «memoria genérica» lleva a tales extremos que en ocasiones se pasan por «cuentos» o «novelas» poemas narrativos (dato que Montesinos, 1961, destaca en su catálogo del siglo XIX). Y es sólo en el siglo XIX cuando comienzan a circular traducciones de Voltaire y de Rousseau.

Hemos aludido a autores filosóficos reconocidos; no faltan los tratados de Holbach, La Mettrie, la Enciclopedia misma, Locke, Hume. De la lista de filósofos franceses, conviene destacar la obra narrativa de Diderot, en especial Les bijoux indiscrets, prohibida en 1761, que nos conduce a un terreno inexplorado de la historia de la censura y la comunicación literaria: los textos calificados de eróticos, lascivos - pornografía - La novela es particularmente vulnerable, si bien no carecemos de ejemplos en la poesía, y sobre todo, en el «papel menudo»-los romances procaces y obscenos que tanto preocupan a los ilustrados (Zavala, 1978)-. La literatura imaginativa ya había sufrido paralizadores ataques desde el Indice de Sotomayor en 1640; sabemos que $L a$ Celestina, publicada en 1499, fue denunciada varias veces al Santo Oficio por su carácter inmoral y por la procacidad de su estilo. Siglos antes no sufrió más que algunas tachaduras, pero en 1793 recibió una prohibición total de la Inquisición, desatada a raíz de una denuncia anónima contra el pintor Luis Paret, que la tenía en su poder (Defourneaux, p. 35) ${ }^{3}$. La intransigencia inquisitorial es poco propicia a la creación, pero lo que distingue al calificador del siglo XVIII es que se preocupa más por la literatura de ficción que sus antecesores. Toma conciencia de que a través de la fantasía y la fábula se podía convencer y subvertir a los indoctos, muy a tono con el espíritu de la época, pues sobre todo a partir de finales del siglo XVII, los novadores recurren a nuevas formas literarias para ganar prosélitos. Como botón de muestra, bástenos el comentario de un lector/calificador del siglo ilustrado y la prevención que expresa contra el género novelístico. En censura con-

3 Estoy en desacuerdo con Deforneaux, que sostiene que esta prohibición tardía demuestra el retraso intelectual de los inquisidores. A mi juicio, demuestra todo lo contrario: en lectura concreta en ese momento histórico determinado, la obra se reinsertó dentro de las nuevas corrientes novelisticas en torno al amor y a la pasión. Lectura que pone de relieve la «modernidad» de La Celestina. 
tra Les vicissitudes de la fortune (1770), condenada en edicto de 1806, apoya su juicio negativo sobre la base de que las novelas son:

relaciones fingidas de diferentes aventuras maravillosas o verosímiles de la vida humana.

Todo en materia de novelas es desechable - concluye-, comentario que ha de tomarse muy en cuenta y analizarse a la luz de los cambios sociales y culturales específicos, que incidieron en los sistemas de distribución: la dinámica cultural hacia la democratización de la lengua literaria, los inicios de la democratización de la imprenta, el emisor que busca redes de comunicación más amplias y ensaya nuevas e innovadoras formas literarias dirigidas a un público no aristocrático; la formación de revistas y periódicos, la crítica, los libreros, los editores, el precio asequible. Todos estos cambios favorecen la transmisión de información; el escritor culto recurre al diálogo, al ensayo, el cuento, la novela, para transmitir sus novedosas interpretaciones de la naturaleza y el hombre. Bajo el título de almanaque, carta, viaje, papel, historia, se podían esconder innovaciones peligrosas (Zavala, 1978). La ficción, el mundo del texto, en definitiva, podía revelarles un conocimiento del mundo, algo sobre la realidad, a sus lectores. Aparecen nuevas estrategias textuales, nuevos signos que es necesario reconocer; una producción literaria distinta, que surge a través del fondo de continuidad. Los calificadores acertaron en reconocer las nuevas estrategias textuales narrativas.

En 1744 se calificaba con prevención el libro Viaje de Pablo Lucas, al parecer novela fantástica bajo el nuevo barniz de relación de viaje (Zavala, 1978), que el censor juzga correctamente como novela. Si bien se considera libro inútil para los doctos, puede «lograr éxito entre los ociosos que se llaman entretenidos», motivo por el cual se prohíbe. Otro viaje fantástico, La isla de. los hermafroditas (Colonia, 1724), se concibe en 1747 como contrario a la buena crianza, las sanas costumbres y las leyes eclesiásticas. El texto, según el calificador, encubre una especie de

novela, donde con motivo de viajes [...] se refieren varios sucesos, así de mar como de otros asuntos.

En cuatro adjetivos rotundos resume el calificador la moral natural, defendida por Leibniz y piedra de toque de los enciclopedistas. En la Enciclopedia de Diderot y d'Alembert, bajo la rúbrica Leibnizianisme aparece:

La moral es la ciencia de las costumbres. [...] Por moral se entiende, aquello que en un hombre de bien, equivale a natural.

(Mi traducción) 
La morale est la science de moeurs. [...] On entend par morale, ce qui, auprès d'un homme de bien, équivaut au naturel.

(Proust, 1962, p. 304)

La moral se comienza a plantear al margen de la Iglesia, y se muestra indulgencia y tolerancia por cuanto antes se concebía como contra natura: la pasión, la sexualidad forman parte sustancial de esta nueva libertad propuesta, entre otros, por Bayle y Diderot, es decir, los científicos dieciochescos. A tal punto que el libertino marqués d'Argens, notable polígrafo que vivió en Holanda, defendía el placer individual como derecho civil (Bonnet, 1981, p. 157). En nombre de la ley natural se redefinen costumbres y conceptos y se reelabora una nueva moral sexual en registros literarios que operan cambios de perspectiva y construcción lingüística. En L'entretien entre d'Alembert et Diderot (1769), se enuncia la nueva moral:

Todo cuanto es no puede ser ni contra natura ni fuera de la naturaleza.

[Tout ce qui est ne peut être ni contre nature ni hors nature. (Diderot 1956, p. 380)]

La novela es vehículo primordial de la nueva filosofía; ayuda a liberar las imágenes de las concreciones negativas mediante las cuales el discurso del poder había estrangulado la ley natural. El lenguaje novelístico explora los fundamentos de la moral natural y de una nueva ética sexual. Bien claro lo establece Diderot a través del diálogo entre el médico Bordeau y Julie Lespinasse. Para Bordeau la continencia es el mayor pecado contra natura y el peor de los crímenes:

No acepto ni la castidad ni la continencia voluntarias que son crímenes. contra natura, si se pudiera pecar contra natura, y el primero de los crímenes contra las leyes sociales, de un país donde se medirían las acciones con otra balanza que aquélla del fanatismo y del prejuicio.

[Je n'en accepte pas même la chasteté et la continence volontaires qui seraient les premiers des crimes contre nature, si l'on pouvait pêcher contre nature, et les premiers des crimes contre les lois sociales d'un pays où l'on pèserait les actions dans une autre balance que celle du fanatisme et du préjugé.] (Diderot 1956, pp. 380-381)

Toda justificación teórica de un placer o de una práctica sexual minoritaria, o bien toda filosofía que deriva leyes y costumbres de la naturaleza misma del ser humano, toda pasión provoca la censura. Los libertinos contarán con la transgresión y la subversión a través de la clandestinidad y el anonimato. El discurso sobre la sexualidad manifiesta su autonomía en contraste con el discurso sobre la propiedad y el estado.

El «libertinaje erudito» que se percibe en España ya en el ocaso del siglo XVII, se divulga ahora mediante nuevas estrategias textuales, y la 
novela es su alimento de predilección. Libertinos son Théophile de Viau, Nicolas Restif de la Bretonne, Choderlos de Laclos, entre los más significativos. Muchos debieron de circular, pues el Inquisidor General Agustín Rubín de Cevallos lamenta el número de escritos

o capciosos o descarados, con que los incrédulos y libertinos y otros monstruos semejantes han inundado el orbe de medio siglo a esta parte (Indice, 1747-1789, p. x111).

Tampoco lo ignora Francisco Pérez de Prado y Cuesta, inquisidor, quien escribe en su prólogo al Indice que el desarrollo del comercio trajo como consecuencia impresiones hermosas, llenas de estampas y encuadernaciones atractivas. Nos rodea - concluye- «un libertinaje estragado» (Zavala, 1978, p. 123).

Pese a la virulencia de los ataques, la literatura libertina o novadora no fue totalmente sepultada. Si bien la información que poseemos es fragmentaria (mucho más abundante a partir de 1800), preciso es señalar que la Inquisición no perdió pista de los libros de viajes, las cartas, las relaciones, las confesiones, las historias, rúbricas que encubren a menudo lo que hoy llamaríamos literatura fantástica, literatura utópica, autobiografía, novela epistolar - todas formas de la narrativa más contemporánea y que a menudo trataba sobre el amor y la sensualidad en el siglo XVIII, a partir de 1760 - Si bien son discursos multiformes y contradictorios, se va planteando una disociación de términos entre sexualidad/matrimonio/procreación. Aparecen como oposiciones a la norma lo ilícito, lo prohibido; es decir, todo el lenguaje sobre el deseo, el placer, la satisfacción en nudo de oposiciones contra el matrimonio, la monogamia, la familia, la procreación, el adulterio. Son obras que presentan el dilema entre las exigencias de la pasión y las de la sociedad; lo que distingue el amor real es la pasión, a menudo como elemento asocial y forma subversiva del amor.

Entre estas obras «lascivas» que comenzaron a circular bajo el ropaje de cartas, valga destacar Lettres d'amour de la religieuse portugaise (1669), un best seller del siglo XVIII, tomadas como más o menos fidedignas hasta fecha reciente. El brevísimo texto desconcertó a sus lectores, que las creyeron escritas en portugués por una mujer, monja portuguesa de Beja; hoy sabemos que las redactó el conde de Guilleragues, noble francés, que en cierta medida inició o impulsó el género epistolar moderno, y el tema de la mujer burlada, uno de los discursos en torno a la mujer: el seductor. Tan famosas estas Cartas como Les liaisons dangereuses (1782), de Choderlos de Laclos, una de las obras maestras del género epistolar. Ambos novelistas emplean la seducción textual para convencer a sus lectores; estrategia discursiva que no pasa 
inadvertida a los inquisidores. Las Cartas de la monja portuguesa se prohibieron en 1781 prima classis auctorum prohibitorum; es decir, autor cuyas obras actuales o futuras están todas condenadas en principio. El calificador/lector no se engañó y captó la estrategia textual; en su censura pone de relieve el carácter osado del librito. Son, dice,

\begin{abstract}
cartas de un amor torpe, lascivo, sacrílego; unas cartas que componen un arte complejo de amor más perjudicial que el de Ovidio, con expresiones no obscenas ni groseras, pero tan vivas, tan afectivas y tan patéticas en los sentimientos fogosos de la sensualidad, que son capaces de encender este pestilente fuego en los ánimos de más candor (Defourneaux, 139).
\end{abstract}

Todavía entre 1814-1820 el fantasma de la monja portuguesa seguía amenazando a los inquisidores, pues aparece citada con cierta frecuencia en las censuras. Las cinco cartas de la monja a su amante, un oficial del ejército francés que la burla, se vendrán a conocer en el suelo español entrado el siglo XIX y sobre todo en el siglo $\mathrm{XX}^{4}$.

Una de las cumbres de la novela epistolar sobre seducciones y libertades sexuales, Las amistades peligrosas, sufrió igual destino: en España se la prohibió por disoluta y lasciva. Un documento inquisitorial de 1791, sin desperdicio, prueba cuán inteligentemente el lector captó las estrategias narrativas:

Hacen de principales personajes en esta escena una mujer joven y viuda, la mayor puta que se halla en las historias y que se intitula la marquesa de Merteuil, y un soltero que se llama el conde de Valmont, que constituye toda su felicidad y su mayor gloria en excederse a todos los jóvenes de París en la disolución (Defourneaux, p. 141).

Y razón no le falta a este agudo inquisidor que percibió en el texto una defensa de la moral natural. A partir de esta novadora vertiente ideológica, el putanisme o libertad sexual, representa un ideal moral puesto que está apoyado en el derecho natural. Esta filosofía naturista se exploró, sobre todo, a través de la narrativa, y es tema preferido de Diderot y Restif de la Bretonne, entre otros. Valga subrayar que cuando los libertinos emplean la palabra puta o prostitución llevan a cabo una deconstrucción de sentido, a través de un desplazamiento de connotación, adjudicándole otro valor semántico al término en el orden de la filosofía natural. Es simple y llanamente una subversión de significado. El contraste entre la connotación y la denotación en una y otra esfera del código es notable; todavía en el siglo XIX esta deconstrucción es válida, pues Charles Fourier emplea también ambos términos de for-

4 En España comenzó a difundirse en el siglo XX; hace unos años se hizo una pelicula poco afortunada del mismo título. 
ma positiva en su Le nouveau monde amoureux (1820), apasionado alegato en favor de la libertad sexual.

Tampoco los inquisidores dejan de lado las estrategias textuales y los mensajes de Defoe, Swift, l'abbé Prévost, L. Sterne, Mme. de Graffigny, Sade y Montesquieu, cuyas Cartas persas se prohibieron en 1797. Para cada uno de estos autores se alegaron distintas razones: herejía y obscenidad son las más frecuentes. Diderot fue condenado tres veces: por sus Pensées philosophiques en 1766, Les bijoux indiscrets en 1761, y finalmente Jacques le fataliste (1778), novela póstuma, se prohibió en 1806. Poco antes de desaparecer la Inquisición se volvió a calificar su obra y desembocó en una condena general; Les bijoux aparece como «la obra más hedionda y torpe que ha salido del abismo» (Defourneaux, p. 159). Igual suerte corrió en Francia, pues allí se prohibió en 1746. Algo semejante sucedió a Jean-Baptiste Boyer, marqués d'Argens, cuyas Lettres chinoises, Lettres françaises, Lettres juives, Mémoires secretes de la République des lettres, se condenaron simultáneamente en 1760. Unos años antes se censuró su Philosophie du bon sens en Roma y en Madrid, por incitar al materialismo y a la duda universal.

Mención especial merece el novelista Prévost; en 1756 se prohibió Le philosophe anglais ou Histoire de M. Cleveland, y en edicto de 1785 aparecen las Mémoires et aventures d'un homme de qualité (1720-1732); ambas son importantes en la historia de la novela. Una edición aumentada de la última recibió una condena especialmente rigurosa por la Histoire du chevalier Des Grieux et Manon Lescaut, famosa por las descripciones realistas de las costumbres sexuales. En 1797 se prohibieron sus obras completas en 55 volúmenes. Este mismo año cayeron otras dos novelas de Restif de la Bretonne, Le paysan perverti y La paysanne pervertie, análisis a fondo de los usos y desusos amorosos entre las clases populares. En 1805 y 1806 se le prohibieron también Palais royal y Les nuits de Paris, esta última por obscena y por enseñar tácitamente el «impío» sistema de Spinoza. Este autor, aún poco conocido, es central en la historia de la literatura libertina y utópica; su abultada bibliografía incluye alegatos en favor del amor libre, y la indulgencia hacia la prostitución y la tolerancia sexual. Ataca siempre la moral rigorista de la ley y de la represión.

Restif es además un innovador en materia de lenguaje; con su obra Le pornographe (1769) introduce el término pornografía, que según el diccionario de E. Littré es «celui qui a écrit sur la prostitution». La obra revela una nueva actitud ante las prostitutas; sin tabús lingüísticos, Restif propone una gran reforma social, que desarrolla también en Le gynographe y L'andrographe, especie de trilogía reformista. En 
1781 publicó en Leipzig un gran texto utópico, La découverte australe, ciertamente subversivo. Su gran obra novelística es precursora del realismo; algunos críticos lo llaman el fundador del realismo en Francia, por sus descripciones de lo popular y de las clases pobres. Según Brunetière es «el aventurero del naturalismo», y ocupa un lugar importante en la novela de la Ilustración.

Ninguno de los autores mencionados se difundirá por entonces en España: a Prévost se le publicó en castellano El deán de Killerine (Le doyen de Killerine) en 1800, novela que explora el amor sáfico; y en 1834 salió El pie de Frasquita, de Restif. Robinson Crusoe no se tradujo al castellano hasta 1835 en París, destino semejante al de Choderlos de Laclos, cuya primera traducción al castellano es una parisiense de 1822. Faltaría saber si en las versiones que circularon el traductor cambió el texto para acomodarlo a la moral convencional, como ocurrió con las Cartas peruanas de Mme. de Graffigny, y las Eglogas de Virgilio, en la traducción de Félix Hidalgo ${ }^{5}$. En estos textos el significado se acomodó a los códigos morales de la cultura receptora, tema que merece estudio. Caso verdaderamente notable el de las Lettres de Ninon de Lenclos (1750), novela anónima libertina, que no he logrado verificar si circuló en España en el setecientos; sin embargo, la heroína debe de haber sido conocida como personaje libre e indecente, pues en la España franquista se propone una interesante modificación léxica para una novela de Jardiel Poncela. El texto original decía: «como los labios de una cortesana», y el autor lo cambia a: «como los labios de Ninón de Lenclós» (Abellán, 1980). He aquí un excelente ejemplo de concreción a la inversa, pues lo que era prohibido en el siglo XVIII se convierte en una referencia literaria opaca en el siglo XX. Ninon de Lenclos pervive como el prototipo de la cortesana. Ya la mencionaba como referencia opaca el duque de Rivas en su discurso de contestación a Cándido Nocedal en la Real Academia: Ninon de Lenclos representa la cortesana ideal.

Sin ánimos de agotar la lista, la Inquisición se dedicó a perseguir de manera muy especial y con finísimo olfato, las seducciones, la sensualidad, las pasiones, consciente de que todo ello era terreno fértil entre enciclopedistas, libertinos y filósofos. Muchas obras que exploraban estos temas se condenaban incluso cuando se planteaban como ejemplo de virtud; santas y pecadoras, cortesanas y discretas, la galante y la doméstica, recibieron idéntico destino: la prohibición. Iglesia y Go-

Le debo estos datos a Myriam Díaz-Diocaretz (1982), que ha trabajado la ideología de los traductores. 
bierno desconfiaban de cuanto aludiera a la sensualidad; la Regla VII del Indice es categórica respecto a las obras «lascivas, amorosas y otras». El tema amoroso desarrollado en cartas, viajes, historias, memorias es rigurosamente perseguido en la década de 1740 a 1750; en 1761 cayeron en escrutinio cinco obras de este tema $-L$ 'art d'aimer, $L$ 'art de connaître les femmes, los cuentos y novelas de La Fontaine y Les bijoux de Diderot.

Las confesiones y las memorias encubren a menudo el sacrilegio de la obscenidad y la lujuria. En la alborada del siglo XIX abundan las obras galantes, descriptivas de costumbres y usos sexuales condenados, tema de reflexión de algunos libertinos y anticonformistas. Destacan unas Mémoires historiques de la corte francesa en la época de Mme. de Pompadour (París, 1802), que se prohibieron en España en 1806, y las famosísimas La nouvelle Sapho ou Histoire de la secte ánandryne, en 1805. Esta última revela otro aspecto; en realidad, cuenta la formación de una sociedad sáfica o cenáculo libertino de mujeres creado durante el periodo revolucionario, la secta anandrina; existía también una Logia de Lesbos. La primera fue muy notoria; contaba entre sus asiduas a damas de la alta aristocracia, y estaba presidida por una célebre actriz de la Comédie, Françoise Raucourt, piedra de escándalo de la sociedad parisiense (Peyronnet, 1980, p. 474). Este libro, publicado originariamente en París en 1791, tuvo varias reediciones, y se tomó como alusión a María Antonieta y su círculo de mujeres galantes. Todavía en 1863 se lo catalogaba en Francia como novela licenciosa al estilo de Bretonne (Bonnet, 1981, p. 267). La nouvelle Sapho forma parte de un discurso sobre una sexualidad disociada de criterios morales, donde se presenta a la mujer dentro de códigos subversivos, lejanos de la foemina impotens, tradicional antigua fórmula jurídica. El género culmina en la década de 1770 y son frecuentes en Francia las cartas, las memorias sobre actrices y los testimonios sobre la vida del teatro, así como las historias de monjas, las voluptuosidades conventuales, las cartas galantes y filosóficas, tal las Lettres galantes et philosophiques de deux nonnes publiées par un apôtre du libertinage, prohibidas en Madrid en 1797. Monjas, damas y actrices se cruzan cartas sobre sus aventuras amorosas en esta nueva gama temática; libros y folletos aluden a academias y sociedades de mujeres, y abundan las alusiones sarcásticas al $f u$ ror amoris o antiphisia, epidemia que ha infectado la capital, según unas Mémoires secretes (Bonnet, p. 142), que obviamente representan el discurso masculino.

En otros casos el tema narrado puede ser la libertad sexual entre las vendedoras y obreras capitalinas, la explotación, las seducciones domésticas, el incesto, terreno fértil de la novela decimonónica. Tam- 
bién encontramos el tema de la sexualidad femenina en cuanto objeto de placer autónomo, recordemos al pasar La Religieuse, de Diderot, que no aparece en edictos en España, pero se publicó en París en 1821 en traducción adjudicada a Marchena ${ }^{6}$. Dentro de esta esfera de la nueva moral, se prohíben en 1769 las Mémoires pour servir à l'histoire de Don Dirrag et de Mlle. Eradice: la $1 .^{\text {a }}$ parte es Thérèse philosophe y la 2. ${ }^{\text {a }}$ Histoire de Mdme. Poislaurier, novela erótica atribuida al libertino marqués d'Argens. Ambas presentan un alegato en favor del placer individual como derecho público. De tenor semejante Félicia ou Mes fredaines (París, 1798), de Andréa de Nerciat, prohibida en Madrid en 1801, obra que describe la iniciación de una mujer en un grupo libertino.

Con agudeza característica Baudelaire llama a esta familia espiritual lejana los «voluptuosos», al elogiar a Choderlos de Laclos. Muchos de los autores que hemos mencionado se prohibieron en Francia entre 1815-1830, es decir, durante la Restauración. En 1826 una nota de la policía francesa mandó suprimir de los gabinetes de lectura los libros que habían aparecido en el Indice como inmorales o irreligiosos (SaintGérard, 1980). Heredero directo de estos códigos y subversiones, Baudelaire padecerá juicio en 1863 por sus composiciones Lesbos, Femmes damnées, Les Bijoux, poemas donde emplea un lenguaje emancipatorio para la voluptuosidad y èl erotismo. Pero la voluptuosidad tenía un sentido ético profundo para los libertinos: el placer físico, el abandono a los impulsos naturales, permitían alcanzar el nudo ideal del tiempo y la eternidad, la unión del alma y del cuerpo. El placer se plantea, en definitiva, como un escape de la angustia, de la temporalidad y de la relatividad universal. Sólo el placer, en su propio absoluto, libera al ser humano -según la filosofía naturalista - del espacio y del tiempo. En palabras de La Mettrie: «ce n'est point la jouissance des corps, c'est celle des âmes qu'il me faut» (L'art de jouir [1751], Oeuvres philosophiques [1764], II, p. 217). Los libertinos dieciochescos glorifican el placer y la pasión. Esta filosofía está orientada en el siglo XX hacia la textualidad como sexualidad, el «placer del texto», en expresió de Roland Barthes ?.

En estos textos setecentistas calificados de «lujuriosos» y «obscenos» se encuentran la tradición de Aretino y la nueva moral sensualista y ma-

6 En Francia se prohibió en 1824, y en 1966 se censuró una película basada en la novela, dirigida por Jacques Rivette.

7 En cuanto imagen visual, esta filosofía sensual es el sustrato de la famosa película de Kurosawa, $L$ 'empire des sens, inspirada también en Georges Bataille. 
terialista que alimenta el libre examen y la tolerancia, frente al conservadurismo de las instituciones en el poder. El lenguaje autoritario del lector privilegiado de la Inquisición se revela justamente en el léxico empleado para definirlos: indecente, vulgar, obsceno, lujurioso -léxico que suprime y reprime la sexualidad-. No menos revelador del discurso del poder es censurar de forma negativa «la tolerancia», motivo que se alegó con frecuencia para prohibir algunos textos. En desplazamiento de connotaciones, los grupos autoritarios del poder censuran y prohíben cuanto es signo de tolerancia y libertad, mediante un lenguaje que convierte en indecente e inmoral toda expresión contra sus normas. Las pugnas que he descrito permiten reconstruir con signo positivo cuanto era entonces motivo de herejía.

Pero no andaban mal encaminados los lectores/calificadores; esta literatura (al igual que la clandestina popular) contó con buen número de lectores. En su mayoría son textos subversivos, a menudo publicados en el anonimato o clandestinamente; se empleaban también para difundir la chismografía palaciega, las crónicas escandalosas y las historias escabrosas sobre la vida privada de nobles, gobernantes, eclesiásticos. Vistos a distancia, el objetivo de estos textos era mostrar que los grupos de poder no estaban capacitados para gobernar. Se proyectaba una imagen negativa, con el propósito de desmontar los símbolos políticos y desinflar sus mitos. La difamación servía para crear un clima de tolerancia: nadie estaba exento de pecado, todas las clases y estados transgredian la moral natural; las instituciones represivas y los gobiernos tiránicos, el fanatismo y el prejuicio eran dique del libre curso de las pasiones humanas (Zavala, 1980).

En este contexto represivo/subversivo se comprende mejor la prevención inquisitorial contra la novela. Los autores y textos que he mencionado representan una gama de las más interesantes innovaciones de la narrativa desde el siglo XVII: la novela epistolar, la novela racionalista, la novela filosófica, y los primeros brotes de la novela realista. En cuanto receptor privilegiado, la Inquisición fue un filtro eficaz que impuso las normas fijadas por el poder de donde emana. Estos impedimentos y trabas - que se mantienen a través de otras instituciones en el siglo XIX y luego en el siglo XX - permiten explicar desde otra perspectiva la escasa producción novelística nacional dieciochesca y la timidez inicial de sus innovaciones. A la luz de este contexto de censura y concreciones podremos quizá comprender la exigua producción novelística peninsular durante los siglos XVIII y XIX, momentos de impulso del género novelístico.

Los ejemplos de género narrativo que hemos analizado se suelen 
catalogar bajo las rúbricas de obsceno, lascivo, contrario a la moral: es decir, de pornográficos o clandestinos en la acepción que hemos subrayado. Esta particular lectura o catalogación se comprende en el contexto de una narrativa, dimensión de la filosofía, cuyo propósito central es la transmisión de conocimientos y la persuasión de determinados públicos. La definición que sobre la novela ofrece la Enciclopedia permite esta vertiente; también en su Elogio a Richardson (1762), Diderot reivindica el género y aclara que si antes fue un tejido de quimeras y frivolidades, peligroso para el buen gusto y las costumbres, permite ahora una elaboración artística de la vida cotidiana y pintar las pasiones en el curso real de la vida, y que además es un instrumento de formación moral. Se concibe que el componente estético de la novela permita hacer vivir las tesis abstractas en la imaginación; los personajes adquieren así dimensión ejemplar. De ahí surge la necesidad de ser realista; en definitiva, la novela filosófica culmina en el realismo. En cuanto transposición de una experiencia moral laica, rompió tabús en el terreno social y psicológico, transmitiendo información sobre algunos aspectos de la realidad que determinados grupos del poder preferían ocultar o evadir.

Todo entra en el mundo novelístico; algunas de las prohibidas que he analizado exploran las pasiones, otras amenazan la estabilidad política mediante la utopía o bien presentan transposiciones geográficas que permiten al lector obtener información sobre distintas sociedades. El repertorio de textos novelísticos censurados representa una buena selección de obras que recodifican la filosofía materialista en una combinatoria de tradición y modernidad. En algunos casos - Defoe, Swift, Prévost, Sterne, Diderot - el héroe no aristócrata vive según valores morales superiores a los de las clases privilegiadas. A veces, se le presenta como un aventurero cuyas peripecias permiten al lector mirar con ojo crítico las convenciones y normas sociales al uso. El elemento de ficción asegura que el héroe no será castigado ni estigmatizado, sino que triunfará finalmente (happy ending). Este triunfo o ascenso social a su vez sustenta el ángulo crítico de este punto de vista (elemento explorado por W. Iser para la novela inglesa, 1975, p. 30).

Otras novelas confrontan el problema de la verdad y la mentira (ficción), tal las Cartas de la monja portuguesa, asentadas en la dialéctica pascaliana. Las cinco epístolas de este texto representan un modelo de lectura e inauguran el género epistolar - la carta que no logra respuesta, muy distinta de la carta sin destinatario específico-. La realidad humana se percibe a través de los movimientos anímicos de la narradora; tan verosímil es su pasión, que en 1810 se le adjudicó el texto a María Alcoforado. Durante más de un siglo se le atribuyeron a esta monja de Beja; la autoría, por lo visto incontestable, pertenece al con- 
de de Guilleragues, autor también de una mediocre colección de poemas.

La culminación del género es Las amistades peligrosas (Mylne, 1965; Todorov, 1967), y gozó de gran éxito en Europa. Algo distinta es la novela de Diderot, Jacques le Fataliste, inspirada en los experimentos de Swift y Sterne; se narra la vida de un valet inteligente y culto que cuenta sin gazmoñería su buena fortuna. Es realmente una kermesse de ideas, en vías de revalorización. Les bijoux, en cambio, imitan a Crébillon hijo, y si bien son procaces y atrevidas, contienen excelentes cuadros de costumbres. El Candide, de Voltaire, considerado hoy día como una de las cumbres del cuento filosófico, opone a la teología cristiana y al optimismo estoico de Leibniz, la ciencia y el empirismo de la naturaleza. El texto vino a circular en España en versión castellana hacia 1838; otras de sus novelas, traducidas por Marchena, no se publicaron en Burdeos y en España hasta 1836.

He aquí filtrados y prohibidos los experimentos de narrativa dieciochescos, textos que posiblemente circularan sólo en la clandestini$d a d$, factor que encarecería el libro hasta hacerlo casi prohibitivo. Los intentos de Cadalso, Isla, Montengón, Mor, por distintos motivos, no encontraron terreno favorable; si bien Cadalso e Isla gozaron de cierto éxito, sus innovaciones narrativas no dejaron mucha huella. A partir de la década de 1830 comienza el desborde de traducciones de novelas, sobre todo francesas, hasta que surjan los primeros ejemplos de novela histórica, modelados en Walter Scott (que no tuvo muchas trabas censoriales). Razón no le faltó a Feijoo cuando escribe, a mediados del setecientos, «concepto inglés en pluma francesa», para definir su época.

La actividad censora de la Inquisición ha sido en el mundo hispánico mediador enérgico de la comunicación literaria en niveles culturalmente importantes. Desempeñó un papel activo como receptor privilegiado, y eligió con gran selectividad las relaciones de intercambio literario. En cuanto receptor privilegiado, formó una particular tradición literaria en un proceso que supone la apropiación y el rechazo de lo nuevo y la conservación del pasado. Su función en el núcleo de la red comunicativa ha permanecido oculto, aunque su intervención ha influido en las normas y en la serie literarias. Su particular recepción del nuevo discurso multiforme de la novelística dieciochesca permite que podamos hoy contar con un repertorio de tipos y de formas de recepción extremadamente diferenciados. En cuanto receptor, la Inquisición nos reserva otra sorpresa: llega incluso a crear nuevas formas, a través de lo que Harold Bloom (1975) denomina creative misreadings. Su celo indujo a los calificadores a corregir y desviar de sentido muchas obras de 
autores conservadores, Burke, por ejemplo. Dentro de su función mediadora dio orientación distinta a otros mensajes: el censor de Atala, de Chateaubriand, se preocupa por la fuerza de las pasiones, en una novela que dista mucho de ser audaz o herética. Según el documento, «el amor desordenado y vicioso que se advierte entre los salvajes [...] es bastante motivo para criticarla y censurarla como ajena e indigna de cualquier cristiano». No consta que el Tribunal Supremo la condenase, pero este receptor captó con certeza que el mundo de la ficción permitía describir las pasiones amorosas como ocurrían en la vida, ofreciéndole al lector un conocimiento del mundo en una moral natural laica. Campo de exploración de Diderot, Richardson y otros narradores ilustrados.

Los estilos, los temas, los géneros, reaparecen en el horizonte en movimiento de su significación. También es cambiante la posición de los intérpretes en su función de concretadores de sentido. Los documentos y juicios nos permiten reconstruir los textos en la historia de su recepción; en un marco de relación dialógica. Permiten, en definitiva, reproducir hoy día la relación entre los receptores/calificadores y los receptores coetáneos entre sí. A partir de este esquema comunicativo, será posible tal vez establecer gradaciones sobre los caracteres de un género, y situarlo en su trayectoria histórica.

$\mathrm{Si}$ adoptamos esta propuesta, parece evidente que el Santo Oficio representa un hito importante en la serie literaria. Si bien se continuó transmitiendo la información en una situación represiva y en circunstancias sociales y políticas poco propicias, la censura provocó una ruptura en el diálogo entre autor y lector. En cuanto receptor privilegiado, limitó la selección de obras del género novelístico a unas pocas categorías. Los índices de libros prohibidos, las requisiciones, los edictos, révelan una especie de centro de distribución y redistribución de códigos, que permite vislumbrar el proceso de producción de nuevos signos que tardaron en incorporarse y producirse. En algunos casos, la nueva combinatoria de rasgos quedó limitada a grupos reducidos de lectores coetáneos. La narrativa -o ciertos aspectos innovadores de la narrativa - quedó relegada a un arte de periferia, hecho de consecuencias significativas en la evolución literaria. Los elementos innovadores tardaron años en hallar un continuador, y éstos se dan sobre el fondo de la continuidad o «memoria genérica» de las estampas y cuadros costumbristas que se publicaron en los periódicos y en los almanaques del siglo XVIII. La ampliación de estas formas produce nuevos modelos estructurales y los elementos innovadores del realismo. La narrativa deja de ser el arte periférico a que estaba reducida por la Inquisición. La posibilidad de relacionar la historia de los géneros con este grupo de re- 
ceptores privilegiados, puede arrojar - creo- fecundos resultados que contribuyan a aclarar la serie literaria.

\section{REFERENCIAS}

ABELLÁN, Manuel L. (1980). Censura y creación literaria en España (1939-1976). Barcelona, Ediciones Península.

Alonso, Dámaso (1963). Pról. Obras en verso del Homero español que recogio Juan López de Vicuña. Madrid.

Alvarez MiRAnda, Pedro (1980). Ed. Tratado sobre la Monarquia Columbina. Una utopía anti-ilustrada del siglo XVIII. Madrid, El Archipiélago.

Backzo, Bronislaw (1971). «Lumière et utopie. Problèmes de recherches». Annales 26, 355-386.

BakTin, Mikhail (1981). The Dialogic Imagination: Four Essays. Michael Holquist, ed. Austin, Univ. of Texas Press (escritos entre 1925-1934).

BLooM, Harold (1975). A Map of Misreading. New York, Oxford Univ. Press.

BONNET, Marie-Jo (1981). Un choix sans équivoque. Denoë, Paris.

DEFOURNEAUX, Marcelin (1973). Inquisición y censura de libros en la España del siglo XVIII. Madrid, Taurus (1. ${ }^{\mathrm{a}}$ ed. fr. 1963).

DiAZ-DIOCARETZ, Myriam (1982). Reading and Writing in the Act of Translation. Tesis Dr. Comparative Literature. SUNY at Stony Brook, 1982.

DIDERot, Denis (1956). Oeuvres philosophiques. Paris, Garnier.

FERRERAS, Juan I. (1973). Los orígenes de la novela decimonónica (1800-1820). Madrid, Taurus.

- (1979). Catálogo de novelas y novelistas españoles del siglQ XIX. Fundación Juan March-Cátedra.

GONZÁleZ PALENCIA, Angel (1934-1941). Estudio histórico sobre la censura gubernativa en España. 1800-1833. Madrid, 3 vols.

HERR, Richard (1964). España y la revolución del siglo XVIII. Madrid, Aguilar (1. ${ }^{a} \mathrm{ed}$. inglés, 1958).

ISER, Wolfgang (1975). «The Reality of Fiction: A Functionalist Approach to Literature». New Literary History, VII, 1,7-38.

JAUSS, Hans Robert (1978). Pour une esthétique de la réception. Paris, Gallimard (comp. desde 1967).

LOPEZ, François (1981). "Considérations sur La Sinapia», en La contestation de la société dans la littérature espagnole du Siècle d'Or. Toulouse, Université de ToulouseLe Mirail.

MCClelland, I. L. (1970). Spanish Drama of Pathos 1750-1808. Liverpool, Liverpool Univ. Press, 2 vols.

MONTESINOS, José F. (1961). Introducción a una historia de la novela en España en el siglo $X I X$. Madrid, Castalia.

MOREL FATIO, F. (1897). «Marchena et la propagande révolutionaire en Espagne en 1792 et 1793». Revue Historique, XIV, 72-87.

MYLNE, Vivienne (1965). The Eigteenth Century Frenh Novel. Techniques of Illusion. London, Manchester Univ. Press. 
Peyronnet, Pierre (1980). «Le péché philosophique», en Aimer en France 1760-1860. T. II, 471-477. Université Clermont-Ferrand.

Proust, Jacques (1962). Diderot et l'Encyclopédie. Paris, A. Colin.

SPELL, R. H. (1938). Rousseau in Spain and the Spanish World. Texas.

SAINT-GÉRARD, Jacques P. (1980). «L'amour: Erotisme, pornographie et normes littéraires (1815-1845)", en Aimer en France, T. II, 191-204.

SARrAILH, Jean (1954). L'Espagne éclairée de la seconde moitié du XVIII e siècle. Paris.

TODORov, Tzvetan (1967). Littérature et signification. Paris, Gallimard, 13-37.

ZAVALA, Iris M. (1969). «Los reformadores y la Inquisición. Notas sobre un caso olvidado". Revista Vascongada de Amigos del País, XXV, 243-253.

- (1975). «Clandestinidad y literatura en el setecientos». NRFH (Hom. a Raimundo Lida), XXV, 2,398-418.

- (1978). Clandestinidad y libertinaje erudito en los albores del siglo XVIII. Barcelona, Ariel.

- (1980). «Entre ciegos anda el libro», en El texto en la Historia. Madrid, Nuestra Cultura, 155-183.

- (En prensa). «La Inquisición: lector privilegiado del discurso autoritario del setecientos», en Homenaje a José A. Maravall. Madrid. 